\title{
STRYKER HISTORY - PROOF OF STRYKER VISION
}

\author{
Csaba Muraközy \\ Scanmedic Kft. \\ scanmed@hu.inter.net
}

\section{Early Beginnings 1939}

What today is the Stryker Corporation, began with the vision of a practicing orthopaedic surgeon and brilliant inventor named Dr. Homer Stryker. Beyond creating the most innovative orthopaedic devices, Dr. Stryker had a more important and noble view. "Never make anything just for profit" he said. This simple statement defined the principle that guided Stryker's orthopaedic frame company, which he started in 1939, and continues to guide the Stryker Corporation today.

Dr. Stryker built the company by creating practical devices of real value to his fellow orthopaedic surgeons and patients. The earliest roots of the company can be traced to the invention of the Turning Frame in 1941. The cast cutter, the first of many powered instruments, was introduced in 1945.

Keeping his father's vision as the guiding force for the business, it was in 1955 that Dr. Stryker's son Lee became president of the

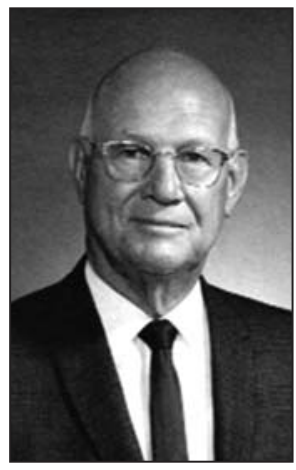

Dr. Homer Stryker

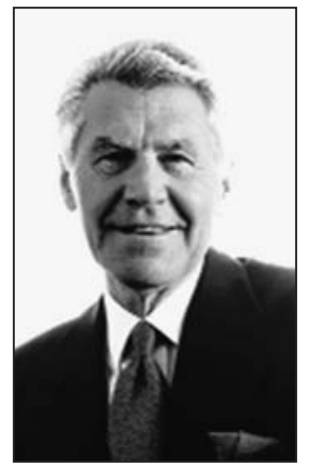

John W. Brown CEO \& President company. For the next 20 years, father and son built a sales and marketing presence around the world. They continued a stream of innovative and practical new products, such as the CircOLectric bed, the world's first hydraulic lift stretcher, the first medical pulsed irrigation system and the first evacuator for bone cement.

1970’s

Following the untimely death of Lee Stryker in 1976, the company began searching for a new leader. Their search ended in 1977 when John Brown accepted the position of CEO and President of Stryker. While the company now had new leadership, the mission for Stryker remained the same.

1980’s

Into the 1980s there were more impressive achievements for the company. In 1981, the Medical and Surgical sales forces were split to increase internal focus and provide better customer service. A Stryker collaboration on an osteogenic protein project with Creative BioMolecules began in 1985. Today, this is the Biotech Division of the company. In the late 1980s Stryker instruments made its mark on the field with the development of batterypowered saws and drills for reconstructive surgery. Then in 1986, Stryker acquired SynOptics, inventors of the first soakable solid state medical video camera. Syn-Optics became Stryker Endoscopy in 1990. 
1990's

The 1990s began for Stryker with its innovative development and marketing of vacuum cement mixing and delivery systems. At the same time, the company was making great strides with powerful micro-electric saws and drills for small bone and cranio-facial surgery. Then in 1992, Stryker entered the spinal fixation business with the acquisition of Dimso. Expansion continued in 1994 with the purchase of a majority investment in Matsumoto Medical Instruments of Japan and the acquisition of Osteo Trauma products in 1996. In 1997 there were two great milestones first sales of monumental proportions were reached with company orders at $\$ 980$ mil-

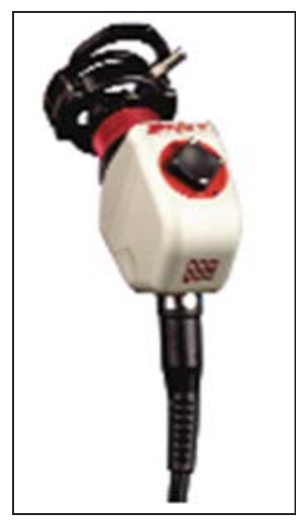

888 Camera lion and earnings growth at $20 \%$ for the $21^{\text {st }}$ consecutive year. Milestone two - Stryker began trading on the New York Stock Exchange.

Stryker comprises now four domestic divisions - Medical, Instruments, Endoscopy and Orthopaedics.

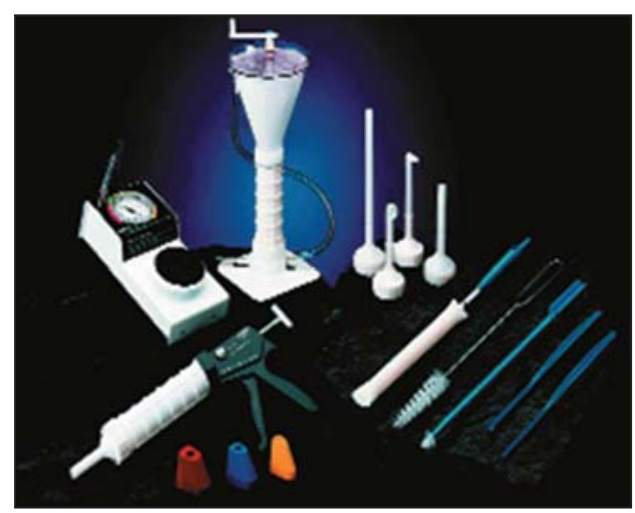

Stryker cementing system

\section{Osteonics}

Osteonics was founded in 1978 by two engineers who conceived the company as a precision cast specialities vendor. It was in 1979, when John Brown realised the great potential of osteonics. That is when Osteonics became incorporated as a wholly owned subsidiary of Stryker. In 1979 introduction of its first hip implants - called the HS1 Stem System and the $\mathrm{HCl}$ acetabular cup.

The 1980s was a decade of tremendous growth and innovation for the company. in 1980 Osteonics introduced its UHR - Universal Head Replacement - for the bipolar hip market. As the 1980s advanced, so did the hip line, with the addition of the Omnifit and Omniflex Hip Systems. In 1988, Osteonics entered the knee implant market and saw sales grow by a remarkable $50 \%$ in one year.

The 1990s were equally successful for the company, with the continued introduction of many new lines, including the Series 7000 Total and Modular Knee Systems, Osteonics Spinal System, Secur-Fit and Restoration Hip Systems, Scorpio total Knee Systems and the Solar Total Shoulder and Elbow Systems. In 1997, the Osteo Trauma Products

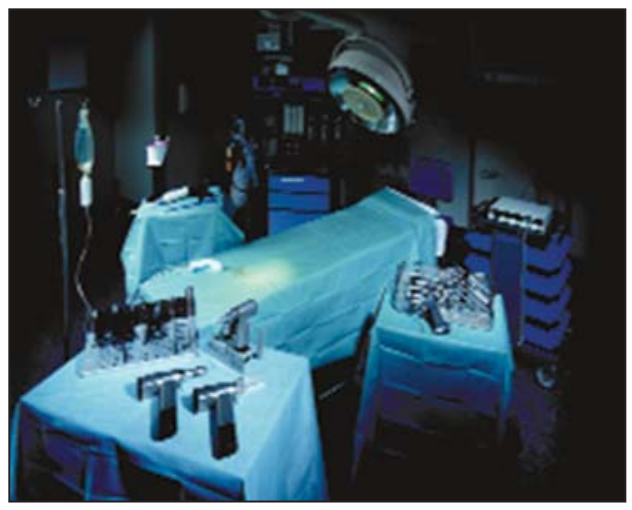

Osteonics 
were introduced, giving Osteonics a full product line offering in the field of Orthopaedics.

What began in 1979 with 6 employees, grew to a company of more than 700 by 1999 and accounted for $40 \%$ of Stryker's billion dollar world wide sales. With the new company Howmedica Osteonics, the prospects for future growth are tremendous.

\section{Howmedica}

Howmedica was founded in the 1930s when it adapted the use of Vitallium alloy - previously used in dentistry, for use in the first Orthopaedic implant. It was used in the manufacture of compression plates and bone screws and later as hip cap prostheses. In 1940, the first femoral hip replacement was performed. The 1950s saw continued growth of the company - then known as the Howe Sound Company. In 1964 it became Howmet Corporation, and finally in 1964 Howmedica was spun off from Howmet.

In the 1970s Howmedica was continuing to revolutionise the orthopaedics industry with innovations such as computer aided design technologies for the design of implants and the introduction of products such as the Harris HD2 Hip System, the Poly-Centric and Geomedic Knees - which were the first non-hinged total knee implants. Howmedica's Universal Instrumentation became the first knee instrumentation system to achieve accurate and reproducible bone cuts. the Total Condylar Knee System, set the standard for the design of all current knee systems. The Exeter cemented hip system was also introduced making the 70s a historic and exciting time for Howmedica.

Through the 1980s and 90s Howmedica continued to innovate and add to its lines with products such as the Luhr MaxilloFacial Micro System, Gamma nails, the ABG Hip System, the MONO-Tube External Fixator System, The Interax and Duracon Knee Systems and three new instrument ranges.

In 1998 Howmedica was acquired by the Stryker corporation to form the Howmedica Osteonics division of the corporation.

On 1 June 2003 Stephen P. MacMillan became Company President and Chief Operating Officer. John Brown remains Chairman
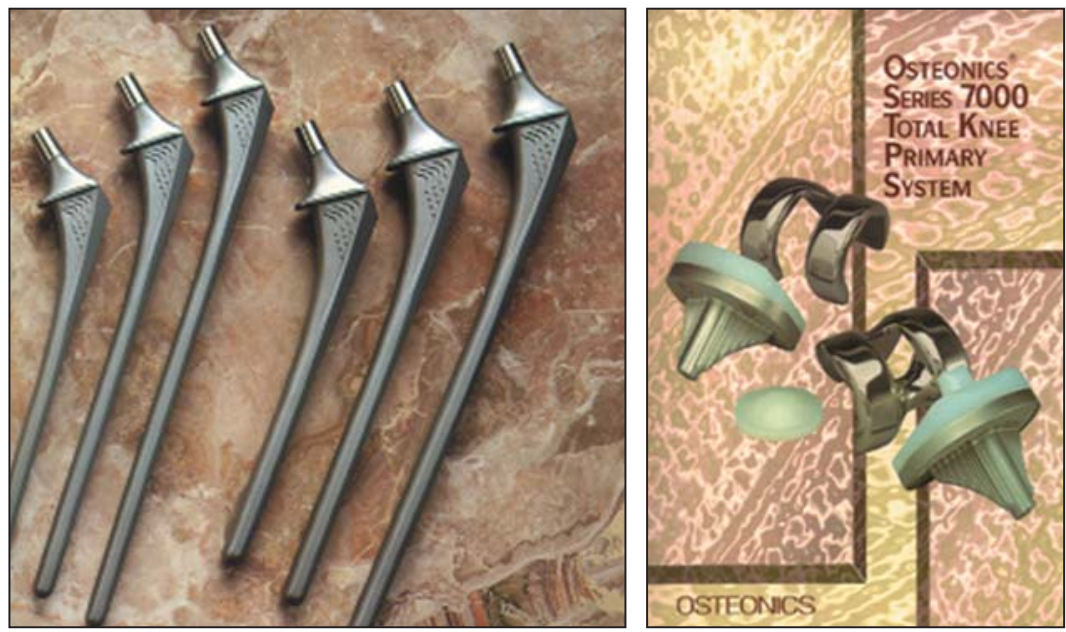


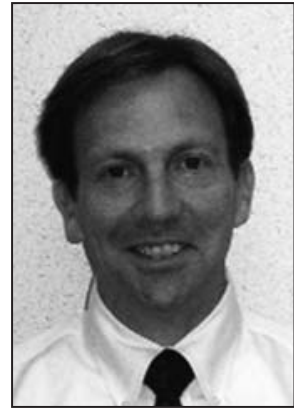

Stephen P. MacMillan Company President and Chief Operating Officer

of the board and Chief Executive Officer. He was appointed from the Pharmacia Corporation and has worked for Johnson \& Johnson, Proctor \& Gamble. Stephen brings a wealth of experience that will go a long way to continuing the demanding growth Stryker expects and will continue Homer Stryker and John Brown's visions for the company.

In 2006 Stryker purchases Sightline, a flexible endoscopy company and enters the GI market.

\section{Csaba Muraközy}

Scanmedic Kft.

H-1089 Budapest, Benyovszky Móric u. 43.

Tel.: (+36) $1333-4259$
With a wide portfolio covered by the divisions of Orthopaedic Implants, Spine, Trauma, CMF, Orthobiologics, Bone Cement, Surgical Navigation, OR Instruments, Endoscopy, Patient Handling and EMS Equipment and US Physical Therapy Services, Stryker becomes a Global Medical Technology Company. The Stryker Corporation becomes a Leader in Orthopaedics, with the most broadly based range of products and services in the market, while having a significant presence in other healthcare specialties and repeatedly investing in some of medicine's most promising technologies.

Stryker Corporation: over 16000 people, working in 14 divisions across the Globe, dedicated to helping people lead more active and more satisfying lives. We give life to a desire to improve medical outcomes that began with Dr. Stryker. 